\title{
The Relationship of Gonadosomatic Index and Hepatosomatic Index in Two Different Age Groups of Common Carp
}

\author{
Lovedeep Sharma* and R. N. Ram \\ Department of Fisheries Resources Management, College of Fisheries, G. B. Pant \\ University of Agriculture \& Technology, Pantnagar, Uttarakhand, India \\ *Corresponding author
}

\section{A B S T R A C T}

\begin{tabular}{|l|}
\hline Ke y w o r d s \\
Age, Common carp, \\
GSI, HSI, \\
Spawning \\
\hline Article Info \\
\hline $\begin{array}{l}\text { Accepted: } \\
\text { 05 February } 2020 \\
\text { Available Online: } \\
10 \text { March } 2020\end{array}$ \\
\hline
\end{tabular}

In the present study, the Gonadosomatic index and Hepatosomatic index of common carp (Cyprinus carpio var. communis) broodstock was evaluated. Both sexes of two different age groups (virgin and 1+ year) were selected for the study. It was observed that all the physico-chemical conditions were optimum. The GSI and HSI values were maximum during March which is supposed to be the spawning season of common carp in India. It was also reported that GSI and HSI had a significant $(\mathrm{p}<0.05)$ inverse relationship. So, present study shows that both GSI and HSI can be used as an indicator of maturity and spawning season of common carp.

\section{Introduction}

Fish is a vital source of protein as well as micronutrients, and enhances the quality of protein in largely starch-based and vegetable diets by providing essential amino acids (FAO, 2006). Study and understanding of fish reproductive biology is a very important aspect to understand its management as well as to increase the commercial aquaculture production (Brewer et al., 2008; Grandcourt et al., 2009; Muchlisin et al., 2010). Reproduction in most teleost fishes in general is a seasonal phenomenon and is limited to a relatively brief longevity (Meijide et al.,
2005; Gopurappilly et al., 2013). Spawning in fish occurs during a particular stage of the reproductive cycle. Fish can spawns once or multiple times annually and the determination of spawning can be identified by Gonadosomatic index (GSI) and Hepatosomatic index (HSI) (Jackson et al., 2006; Alonso et al., 2009; Tubert et al., 2012).

The GSI is used to detect hydrated ovaries in females as well as testis in males and therefore it helps in detection of the reproductive period from weight increase (Hunter and Macewicz, 2001). High value of 
GSI is an indicative of mature stage of gonads i.e; ovary and testis in the fish. The mature ova/ egg are round and heavily laden with yolk (Misra and Saksena, 2012) and due to this reason hepatosomatic index (HSI) is usually used as an indicator of energy reserves in the liver HSI is related with GSI because of vitelogenesis process that synthesizes vitelogenin and in fish, vitelogenin is yolk precursor that synthesized in liver (Cerda et al., 1996). As earlier so many studies were conducted on relation of GSI and HSI, in present study authors aimed to establish the relationship of GSI and HSI in common carp, being the third most widely cultivated freshwater fish of two different age groups (FAO, 2013).

\section{Materials and Methods}

The experimental fishes were collected from Instructional Fish Farm of College of Fisheries, Govind Ballabh Pant University of Agriculture and Technology, Pantnagar, Udham Singh Nagar, Uttarakhand, India. Water quality analysis was also done of the respective pond. Sample of 10 (5 males and 5 females) of Cyprinus carpio var.communisof two different age groups. Length and weight measurements were done and specimens were sacrificed in the laboratory for both male and female gonads and liver collection.

Gonadosomatic index (GSI) of the male and female fishes was determined separately.

GSI $=\stackrel{\text { Weight of gonads (g) }}{\text { body weight of fish (g) }} \times 100$

(Parmeswaran et al., 1974).

Hepatosomatic index (HSI) was calculated as the ratio between liver weight and body weight in grams.

$$
\text { HSI }=\underbrace{\frac{\text { Weight of the liver (g) }}{\text { Weight of the fish (g) }}} \times 100
$$

(Parmeswaran et al., 1974).

\section{Results and Discussion}

The basic objective of the study epitomizes the effect of age on GSI as well as HSI of common carp (Cyprinus carpio var. communis) and also the relation between GSI and HSI. The physic-chemical parameters like temperature, dissolved oxygen and $\mathrm{pH}$ were in optimum range as given in table 1.

In fig. 1it is shown that in virgin group GSI (\%) rises continuously in males from September $(0.54 \pm 0.18)$ to March $(6.96 \pm 1.09)$. And in females a steady increase from September $(1.57 \pm 0.29)$ to March $(8.18 \pm 1.32)$ was observed. In 1+ year group, the female GSI ranged from $2.81 \pm 0.65 \%$ December (min.) to $9.81 \pm 1.32 \%$ March (max.) similarly, in males it was observed that GSI (\%) ranges between $3.58 \pm 0.31$ to $7.20 \pm 1.17$, maximum in March during spawning period as presented in fig. 2. There was a significant difference $(p<0.05)$ in GSI values of both groups age wise as well as month wise.In present study it was also found that there was no much difference in GSI of males of both groups, which is supported by Liley et al., (2002) who stated that there was no differences in the gonadosomatic indices of 3 years old and 1 year old (precocious) male rainbow trout.

In case of virgin group, hepatosomatic index (HSI) ranged between $0.49 \pm 0.41 \%$ to $0.83 \pm 0.06 \%$ in males while in females it varied between $0.67 \pm 0.06$ to $1.54 \pm 0.52$ shown in fig.3. In $1+$ year class, HSI ranged between $0.54 \pm 0.24 \%$ to $1.45 \pm 0.13 \%$ and $0.65 \pm 0.52 \%$ to $1.77 \pm 0.65 \%$, in males and females respectively as shown in fig.4. HSI values shown significant $(\mathrm{p}<0.05)$ difference between two age groups for both sexes.And also by the comparative analysis it was observed in following investigation that there exist a significant $(\mathrm{p}<0.05)$ negative relation between GSI and HSI of the age groups. As GSI was maximum during March while in 
contrast to it HSI was observed to be minimum during the month of March. Singh et al., (2008) also made similar observations of reared and wild female Labeodyocheilus and reported that HSI and GSI had an inverse relationship.

Fig.1 Gonadosomatic index of virgin group of different months

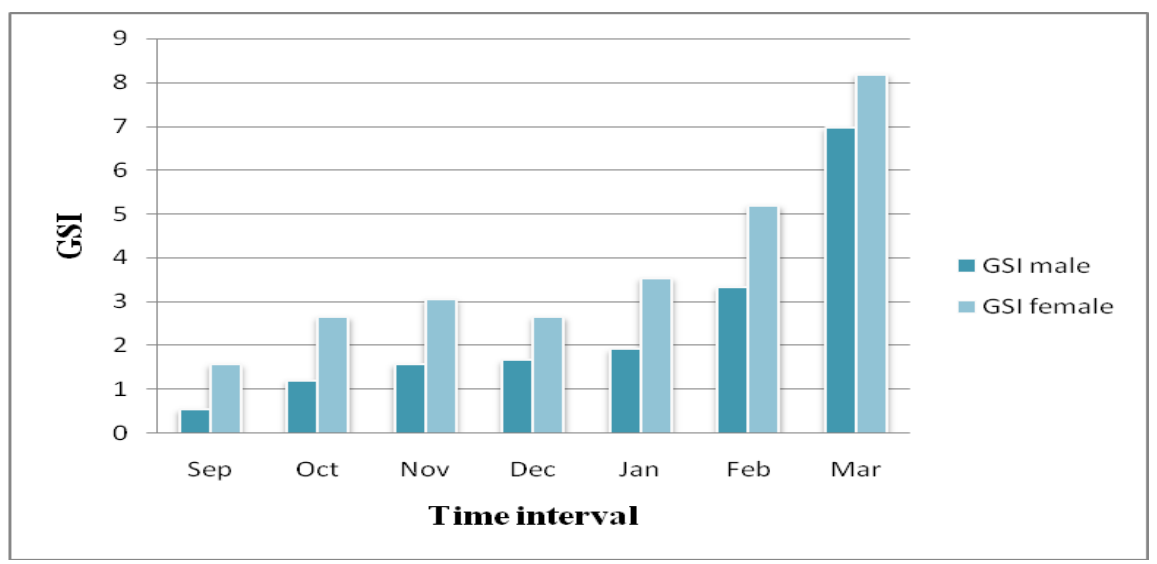

Fig.2 Gonadosomatic index of 1+ year class of different months

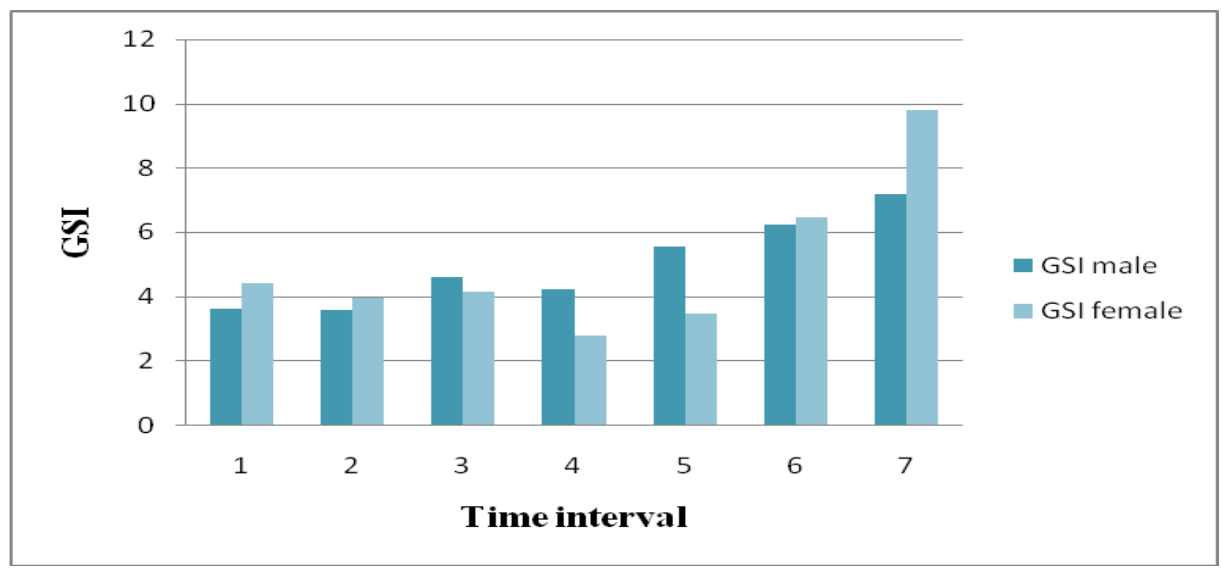

Fig.3 Hepatosomatic index of virgin group of different months

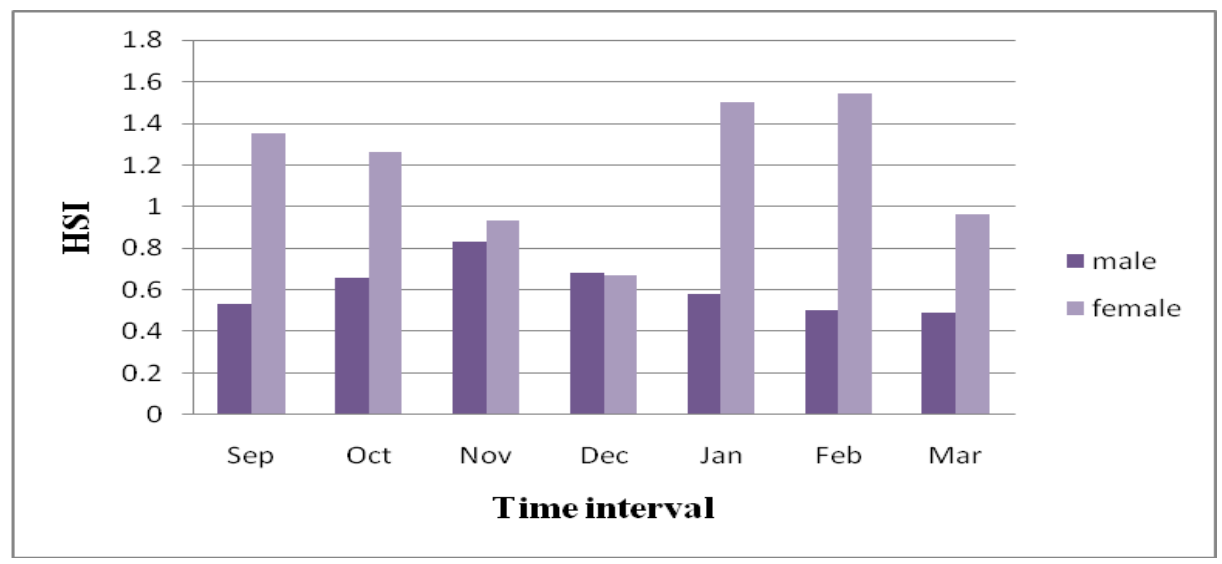


Fig.4 Hepatosomatic index of 1+ year class of different months

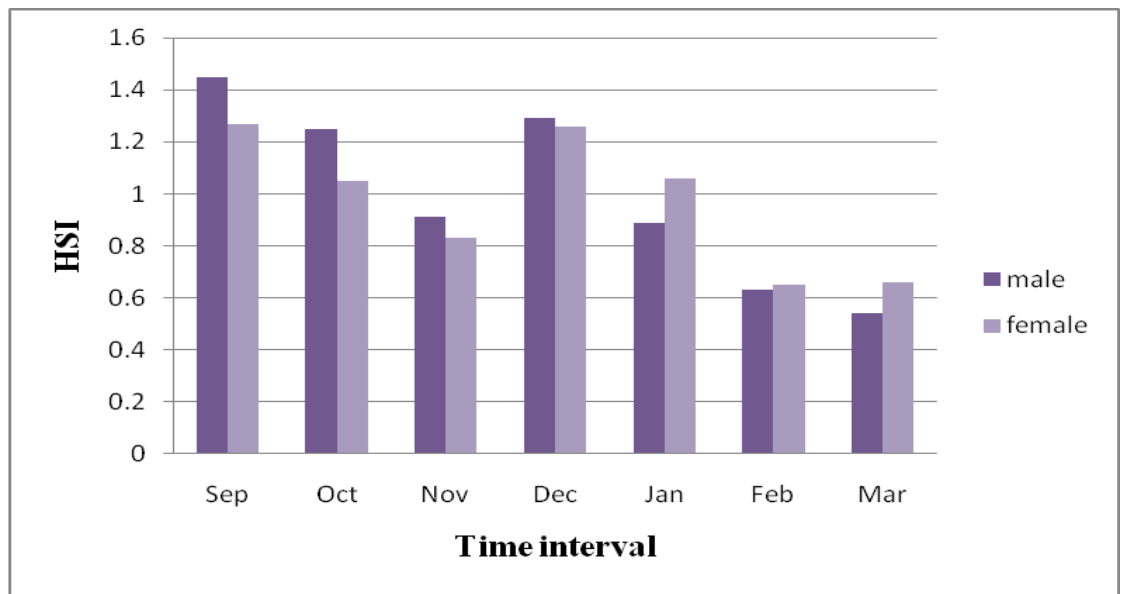

Fig.5 Relationship of GSI and HSI in virgin male (Fig.5a) and female (Fig.5b)

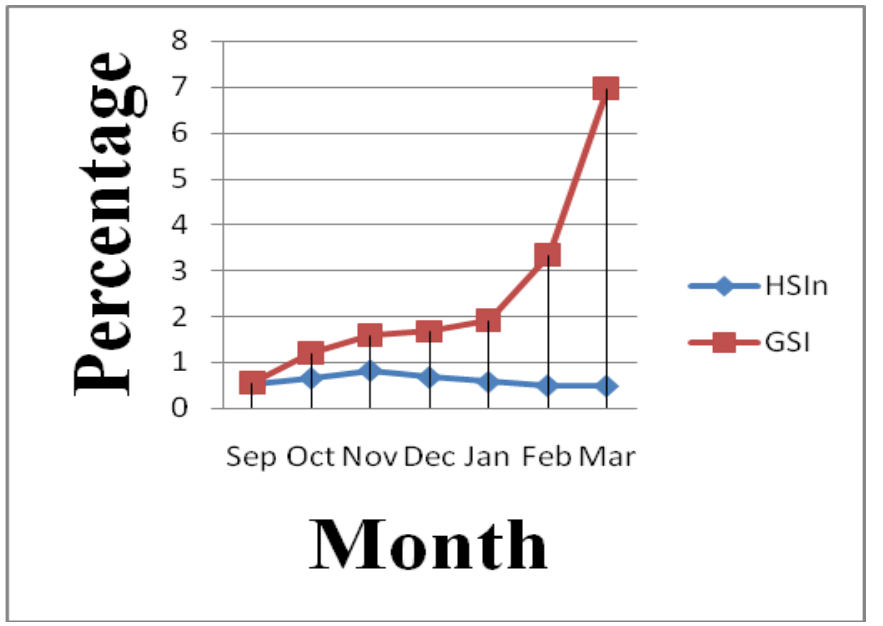

Fig. 5a

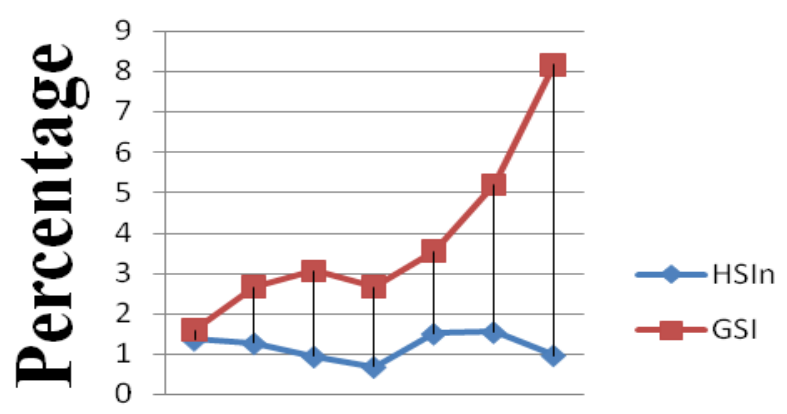

Sep Oct Nov Dec Jan Feb Mar

Month

Fig.6 Relationship of GSI and HSI in 1+ year male (Fig.6a) and female (Fig.6b)

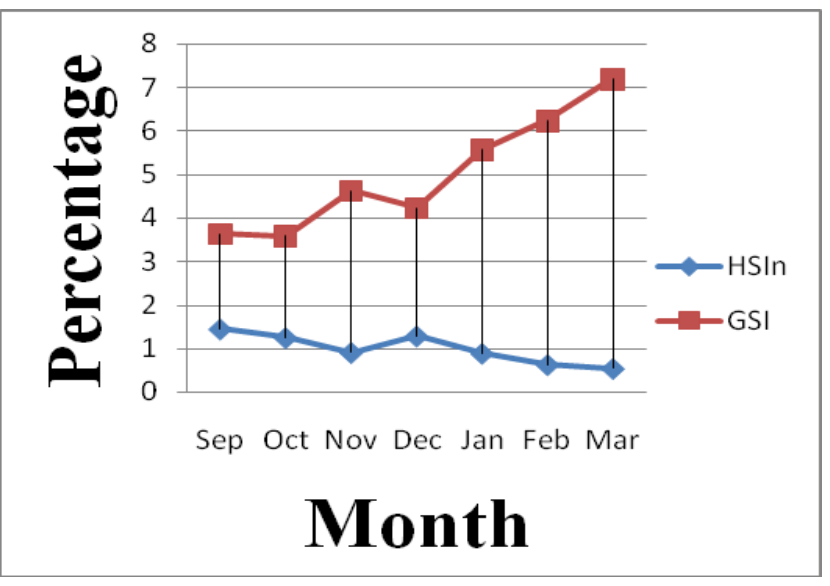

Fig. 6a

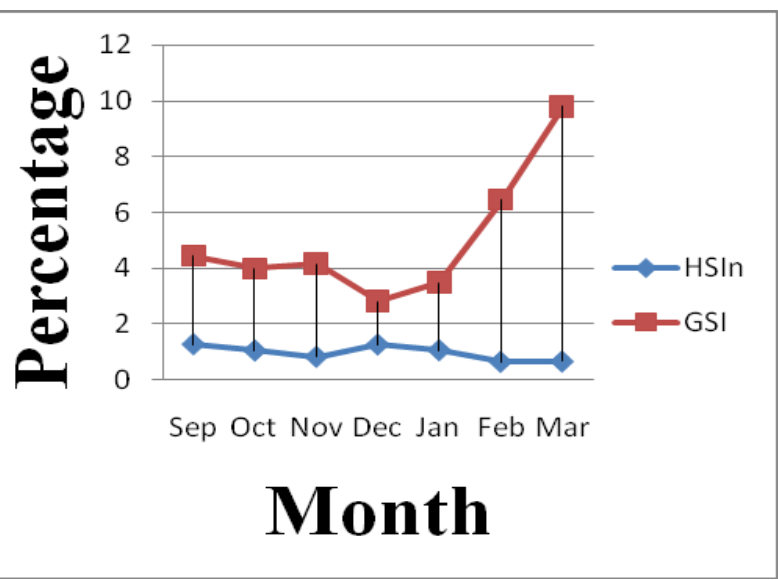

Fig. 6b 
In conclusion, the present study depicts that there was significant difference in gonadosomatic index (GSI) in both male and female (sexes) of both groups i.e.; virgin and $1+$ year, month-wise. Hepatosomatic index (HSI) also showed significant differences month-wise. It was also revealed from the results that there was a negative relationship between GSI and HSI in common carp.

\section{Acknowledgement}

The authors are grateful to the Dean, College of Fisheries, Govind Ballabh Pant University of Agriculture and Technology (Uttarakhand, India) for the funding. And also express their sincere appreciation to the people who gave their time, advice, and support during the experiment.

\section{References}

Alonso, P., Fontes, J., Holland, K.N. and Santos, R. (2009) Multi-scale patterns of habitat use in a highly mobile reef fish, the white trevally, Pseudocaranx dentex, and their implications for marine reserve design. Mar. Ecol. Prog. Ser., 381: 273-286.

Brewer, S.K., Rabeni, C.F. and Papoulias, D.M. (2008) Comparing histology and gonadosomatic index for determining spawning condition of small-bodied riverine fishes. Ecology of Freshwater Fish, 17: 54-58.

Cerda, J.B., Calman, G., Lafleur, Jr., G.J. and Limesand, S. (1996) Pattern of vitellogenesis and follicle maturational competence during the ovarian follicular cycle of Fundulus heteroclitus. General and comparative endocrinology, 103(1): 24-35.

FAO. (2013). Fishstate plus: Universal software for fishery statistical time series (available www.fao.org/fi/statist/fisoft/ fishplus.asp).

Fisheries, F. A. O. (2006)The state of world fisheries and aquaculture 2006.

Gopurappilly, R., Ogawa, S. and Parhar, I. S. (2013) Functional significance of GnRH and kisspeptin, and their cognate receptors in teleost reproduction. Frontiers in endocrinology, 4: 24.

Grandcourt, E.M., Al-Abdessalaam, T.Z., Francis, F., Al-Shamsi, A.T. and Hartmann, S.A. (2009) Reproductive biology and implications for management of the orange-spotted grouper Epinephelus coioides in the southern Arabian Gulf. Journal of Fish Biology, 74: 820-841.

Hunter, J.R. and Macewicz, B.J. (2001) Improving the accuracy and precision of reproductive information used in fisheries: modern approaches to assess maturity and fecundity of warm- and cold-water fish squids. Fishery bulletin, 90(1): 101-128.

Jackson, M.W., Nieland, D.L. and Cowan, J.H.Jr. (2006)Diel spawning periodicity of red snapper Lutjanus campechanus in the northern Gulf of Mexico. J. Fish Bio., 168: 695-706.

Liley, N. R., Tamkee, P., Tsai, R., and Hoysak, D. J. (2002) Fertilization dynamics in rainbow trout (Oncorhynchus mykiss): effect of male age, social experience, and sperm concentration and motility on in vitro fertilization. Canadian Journal of Fisheries and Aquatic Sciences, 59(1): 144-152.

Meijide, F.J., Lo Nostro, F.L. and Guerrero, G.A. (2005) Gonadal development and sex differentiation in the cichlid fish Cichlasomadimerus (Teleostei, Perciformes): A light and electronmicroscopic study. J. Morphol., 264: 191-210.

Misra, S. and Saksena, D. N. (2012) Gonadosomatic index and fecundity of 
an Indian major carp Labeo calbasu in Gohad reservoir. The Bioscan, 7(1): 4346.

Muchlisin, Z.A., Musman, M. and SitiAzizah, M.N. (2010) Spawning seasons of Rasborata warensis in Lake LautTawar, Aceh Province, Indonesia. Reproductive Biology and Endocrinology, 8: 49.

Parameswaran, S., Selvaraj, C., and Radhakrishnan, S. (1974) Observations on the biology of Labeogonius (Hamilton). Indian Journal of Fisheries, 21(1): 54-75.

Singh, A., Singh, I. J., Ram, R. N. and Kushwaha, B. (2008). Ovarian development in Labeo dyocheilus
(McClelland) during active reproductive phase under captive and wild conditions. Journal of Environmental Biology, 29(2): 169.

Singh, A., Singh, I. J., Ram, R. N. and Kushwaha, B. (2008) Ovarian development in Labeo dyocheilus (McClelland) during active reproductive phase under captive and wild conditions. Journal of Environmental Biology, 29(2): 169.

Tubert, C.A., Nostro, L.F., Virginia, A.B, Villafae, A. and Pandolfi, M. (2012) Aggressive behavior and reproductive physiology in females of the social cichlid fish Cichlasoma dimerus. Physiol. Behav., 106: 193-200.

\section{How to cite this article:}

Lovedeep Sharma and Ram, R. N. 2020. The Relationship of Gonadosomatic Index and Hepatosomatic Index in Two Different Age Groups of Common Carp. Int.J.Curr.Microbiol.App.Sci. 9(03): 727-732. doi: https://doi.org/10.20546/ijcmas.2020.903.087 